\title{
Ectoparasite Prevalences of Grouper Fish (Epinephelus fuscogutatus $x$ Epinephelus polyphekadion) Cultured in Floating Net Cages
}

\author{
Sudirman Adibrata ${ }^{1 *}$, Muh Yusuf ${ }^{2}$ and Cristiana Manullang ${ }^{3}$ \\ ${ }^{1}$ Aquatic Resource Management Study Program, \\ ${ }^{2}$ Marine Science Study Program, \\ Faculty of Agriculture, Fisheries and Biology, Bangka Belitung University \\ Kampus Terpadu Universitas Bangka Belitung. Balunijuk, Merawang, Bangka, \\ Kepulauan Bangka Belitung, 33172 Indonesia \\ ${ }^{3}$ Graduate School of Engineering and Scince, University of the Ryukyus, \\ Nishihara, Okinawa, Japan \\ Email: sadibrata@gmail.com
}

\begin{abstract}
Monitoring the health of the reared fish in a floating net cage (FNC) is often conducted by examining their ectoparasites. This study determines ectoparasite prevalences of grouper fish (Epinephelus fuscogutatus $x E$. polyphekadion). The study site was conducted in the Pongok Island, South Bangka Regency. The health examination of fish and ectoparasites was carried out by applying simple random sampling during three periods (November 2016 (I), February 2017 (II) and May 2017 (III)). Hydro-oceanography survey was done every month throughout three years. The grouper checkings (I, II and III) indicated the prevalences of ectoparasites in these periods were $43.3 \%, 8.8 \%$ and $13.5 \%$, respectively. The mortality rate of fish was highly in the period I among other periods while the survival rate at harvesting time was only $70 \%$ from initial seed stocking $(1,500$ fish in total). The intensities ectoparasite throughout the were 1.6, 1.6, and 1.5, respectively. The result implied that every 10 groupers would potentially be attacked by at least 15-16 ectoparasites. A slow seawater current flow triggered the quick uplifting of the ectoparasites from the seafloor. The water condition at the FNC location in 2011 and 2017 was still under the quality standard. The ectoparasites were originated from the surrounding environment of the FNC location. The fish culture management should inevitably focus on cleansing the ectoparasites attaching on the groupers, dusting the net cage clean, and arranging the harvest pattern on a particular month following the surrounding environmental condition to prevent ectoparasite attacks.
\end{abstract}

Keywords: culture, ectoparasite, floating net cage, grouper, prevalence

\section{Introduction}

The current issues regarding mariculture in the floating net cage (FNC) are related to the aspects of location preparedness, production of fish and environment. A proper area of rearing groupers using the FNC system in the research location, the waters of Pongok Island, covers 3,474.66 Ha (Adibrata et al., 2013) while the existing location for running the FNC system is only $\pm 1 \mathrm{Ha}$ until the beginning of 2019. This situation presents a business opportunity for rearing fish in small islands. Additionally, the fish production aspect linked to fish culture trend aims to improve the food security and incomes of fishermen, to ensure natural fish stock sustainably, and to preserve the biodiversity by focusing on the nutrition, survival rate, reproduction, and mortality of fish (Dias et al., 2012). The environment aspect which is highly correlated with water quality reduction has the reciprocal relationship with cultured fish health, food stock, and disease or fish parasite.

Degradation quality of the environment becomes one of the obstacle factors in guaranteeing the sustainability of cultured fish production (Karakassis, 2001). The impacts of environmental factors for mariculture are highly varied depending on species, rearing method, stock abundance, types of food, oceanographic condition, and practices of culture system (Wu, 1995). The dynamics of hydro-oceanography is a given environmental factor; however, other factors can be designed to boost the fish culture business. Evaluating the obstacle factors through monitoring the water quality and fish health status is able to decrease the culture problems in order to devise the best strategy based on the environmental condition in the research location. 
Monitoring is undertaken to acquire related information about health status of fish and the eligibility of the environmental condition in protecting and remediating the cultural environment (Syakti et al., 2012). The cultured fish health could be identified through agility of movement, no injuring physically, proportional in size and no attacking by disease or parasites. The developed fish culture business using the floating cage system, for instance, some domesticated grouper species are not spared of attacking from parasites. The simplest monitoring on cultured fish is thoroughly checking the ectoparasites directly. The main entrances of this biological contaminating agent are by the environment, culture facility (Brown 1993) and fish seed introduction from different hatcheries (Brett et al., 2005). The management of the rearing fish health and its environment is very crucial to boost the cultured fish production sustainably (Novriadi et al., 2014).

Some cultured groupers which are able to be produced in hatcheries are such as humpback grouper (Cromileptes altivelis), tiger grouper (Ephinephelus fuscoguttatus), grouper fish (E. fuscoguttatus x E. polyphekadion) and cantang grouper (Ephinephelus sp, a hybrid from camouglage grouper and giant grouper). Nevertheless, the mentioned groupers above are still possibly attacked by parasites particularly attaching on their skin and gills. The problems regarding ectoparasites in rearing groupers using FNC system can lower the fish production. The grouper ectoparasites originating from Family Cymothoidae (GBIF Secr, 2017) are Cymothoa rhina which is well-recognized in Philippines, Guam, Singapore hosting on Lutjanidae (Bruce et al.,
2016), Ceratothoa imbricata which is well-known in Australia, New Zealand, Indonesia (Hadfield et al., 2014) and Rhexanella sp. which is well-identified in Indonesia and Thailand (Nagasawa and CruzLacierda, 2004). The ectoparasites commonly attach to the outer body part or gill of the fish that then inhibit their growth and even until the death level. This research aims to determine the ectoparasite prevalences on cultured grouper fish (E. fuscogutatus x E. polyphekadion).

\section{Materials and Methods}

This research was conducted in the seawater surrounding Pongok Island at South Bangka Regency. It was geographically situated on $02^{\circ} 53^{\prime} 00 " S$ and 107'01'00"E (Figure 1.). Moreover, it was realized to find out the groupers attacked by ectoparasites in three different periods, November 2016, February 2017 and May 2017. Furthermore, the hydro-oceanography surveys were carried out from November 2016 until October 2017.

The fish that were sampled were the grouper fish (E. fuscogutatus $x$ E. polyphekadion) in the floating net cage (FNC) system. Inventorying fish samples surmised attacked by ectoparasites utilized simple random sampling method where these groupers were only in one stretch of FNC (Figure 1). While the hydro-oceanography survey was taken directly in-situ and the parameters of water quality was analyzed in the Proling Laboratory of IPB University. Additional information was collected by interviewing and secondary data from

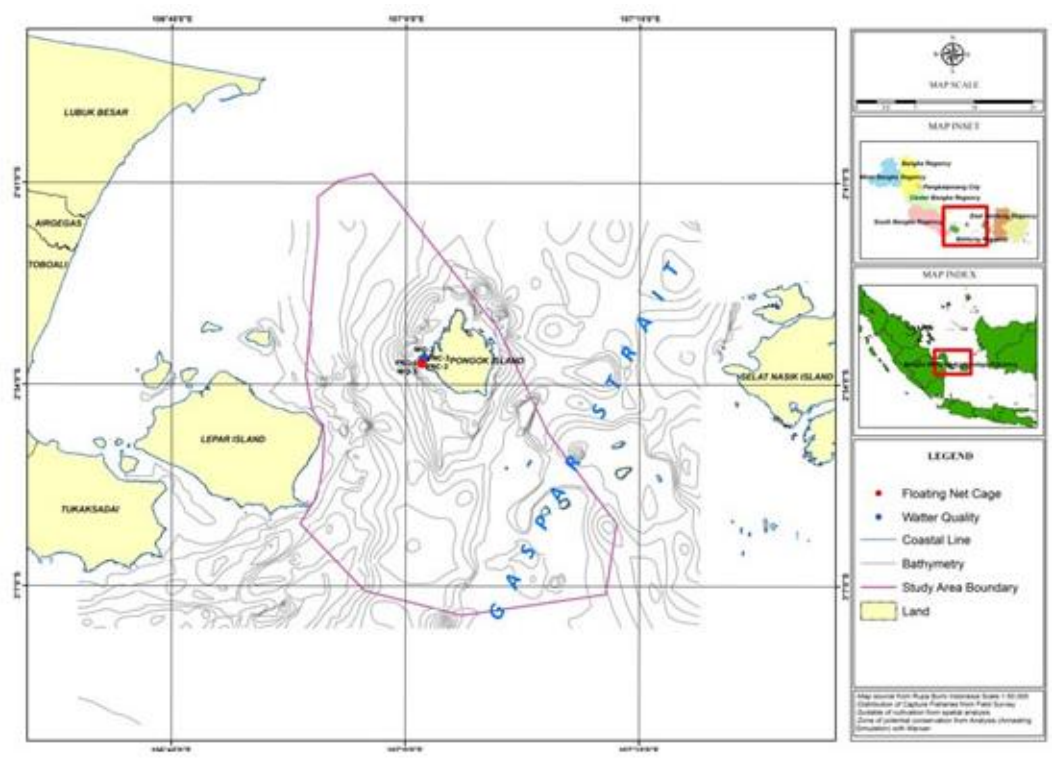

Figure 1. Location of fish floating net cage 
the literature study. Plastic tank, fresh water, hand gloves, syringe, drugs, handline hook, a set of the stationary, ruler and digital camera were used to collect the ectoparasites of the grouper. In additons, current meter, DO-meter, hand refractorsalinometer, secchi disk, a boat with the capacity of \pm 5 GT equipped with GPS map 585 Garmin (defining time, coordinate, temperature and depth of water) and sampling bottles to store the water containing ammonia, nitrate, ortho phosphate, nitrite and leads were obtain for measuring hydrooceanographical and water quality.

The samples collected in this research followed a formula as follows (Krejcie and Morgan, 1970):

$$
n=\frac{\chi^{2} \cdot N \cdot P(1-P)}{(N-1) \cdot d^{2}+\chi^{2} \cdot P(1-P)}
$$

where $: n$ is a measure of the sample, $N$ is a number of population, $X^{2}$ is a value of chi-square, $P$ is a proportion of the population and $\mathrm{d}$ is an estimated error.

The analysis prevalence (\%) for ectoparasites used a formula the number of the nested fish samples divided by the number of checked sampling fish time a hundred (\%). Intensity is the number of ectoparasite $A$ that infects divided by the number of the sampled fish attacked by ectoparasite A. If there were more than one species of ectoparasites, than the calculation of dominance proceeded. The dominance (\%) is the number of ectoparasite species infecting sampled fish divided by the total ectoparasite infecting the sampling fish.

\section{Results and Discussion}

The population of groupers in this research was previously counted before the sampling was taken by interviewing the owner of the floating net cage, each time of fish checking on the three different times of observation. According to the information obtained from the interview of the fish culture owners, the fish stock of groupers on the first period of checking (July 2016) was only relied on supplying coming from collectors in Belitung Regency. Seedlings of this grouper were not always available every time however, adjusting on the existing stock in this regency which originated from either Bali or East Java. The size of seedlings of groupers to be stocked for rearing in the FNC was $\pm 10 \mathrm{~cm}$ of length. In the first period of checking (Checking I), the total population of remain fish seedlings was 1,220 individuals (divided into four
FNC) due to the death of 280 individuals in which the initial total stock of seedlings was 1,500 individuals. According to the calculation, the values of $x^{2}$, level of confidence, degree of freedom, $p$ value and error are 3.841, 95\%, 0.05, 1, 0.5, 0.05 or $5 \%$ respectively. The ectoparasite attaching on both skin and gills of the grouper was identified only one species. The results of fish checkings are shown in Table 1 and Figure 2. Geographically, the FNC location are situated in one area surrounding Pongok Island on the coordinates of 020 52' 36.4"S, $107^{\circ} 00^{\prime} 58.8^{\prime \prime E ; ~ 020 ~ 52 ' ~ 33.2 " S, ~ 1070 ~ 01 ' ~ 04.4 " E ; ~}$ and $02^{\circ} 52^{\prime} 15.7^{\prime \prime S}, 107^{\circ} 01^{\prime} 10.7^{\prime \prime E}$. The analysis results of acquired data are presented in Figure 3.

The hydro-oceanographic condition in the research location surrounding Pongok Island is presented in Table 2. The depth of the existing FNC is about 10 meters located between Pongok Island and Celangen Island. The total area of these FNCs is approximately one hectare dividing into three blocks and situated in one location. The condition of seawater quality parameters in the floating net cage consisting of ammonium, nitrate, ortho phosphate, nitrate, and lead, is listed in Table 3 as follows.

The district of Pongok Islands has an area of $89.67 \mathrm{~km}^{2}$ (BPS of South Bangka Regency, 2017). The use of Indonesian small islands is intended to prioritize the purpose of conservation, education, and training, research and development, marine cultivation, tourism, marine and fish industry, and sustainable fishery industry, organic agriculture, stock raising and/or state defense and security (Constitution No. 27/2007 jo Constitution No. $1 / 2014)$. This district is determined as one of the central areas for catch and culture fishery in South Bangka Regency (Local Government Regulation of South Bangka Regency No. 6/2014) that needs support from all stakeholders in order that the management of these small islands could be optimized and raising the entrepreneurs in the small scale fisheries.

Prevalence is a number of diseases or injury cases presenting in a certain population during a point of time (Kent, 2007). In this research, the prevalence was calculated by comparing the attacked fish of ectoparasites and the total checked fish of sampling where these ectoparasites attaching on both skin and gills. In addition, the failure of culturing fish utilizing the FNC in the waters surrounding Pongok Island was usually related to several factors, namely parasites, fish tired during a transportation process, unpredictable pollutants, virus detected when the fish have grown up, cannibalism if lack of feed or difference in size, weather and extreme environmental factor. For the fishermen of the FNC system, routine checking of 
the cultured groupers aimed to discharge the ectoparasites, to provide vitamin injections, and to short the fish (Figure 2.).

Based on Table 1, the total seedling stock of groupers in all FNC was 1,500 individuals with each size of $\pm 10 \mathrm{~cm}_{\text {. fish }}^{-1}$ in length. The feed in form of drowned pellets were routinely given for two months, and then the cutting fish in pieces and cleaning from spines were administered for the transition period, and eventually, the trash fish were being these groupers' feed. In the fifth month, the reared fish were ready to be checked for attacking parasites by simply checking their skin and gills. When an ectoparasite was found attaching, it was repealed and killed using hands. The attacked fish were then isolated in a tank containing fresh water which had been mixed with a cefotaxime medicine. Another way that has been successfully recognized in controlling the parasites of Goliath grouper (Epinephelus itajara) is by bathing the fish using freshwater over five minutes (Silva et al., 2014). The attacked fish were injected prior before it was released back into the FNC in order to be getting healthy again, no limping, and its appetite increased. Only remained 1,220 groupers in total four FNCs after five months of rearing which were about 305 individuals in each FNC.

The sampled groupers indicate that there was $43.3 \%$ of the fish (Checking I). It means that there are 43 groupers was attacked by the ectoparasites in 100 individuals of the population. This prevalence of ectoparasite is harmly impacted for the fish culture which becomes one of the fish death sources. It was depicted during five months of rearing. There were 280 grouper seedlings death with wounds on skin and gills as well as the injured fish were difficult to eat. Further, the prevalence decreased in the next checking period (Checking II) which was only $8.8 \%$ that was probably due to the three prior months, those fish had been cleaned

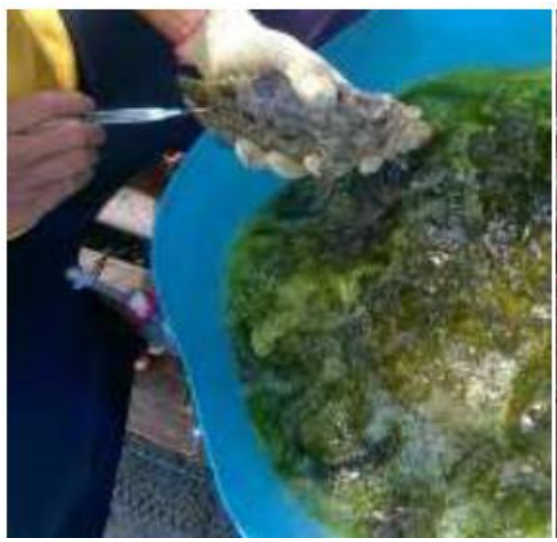

Grouper fish

(E. fuscogutatus $x$ E. polyphekadion)

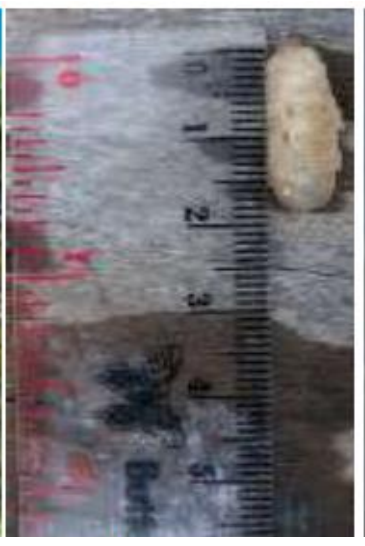

Ectoparasite in a real size

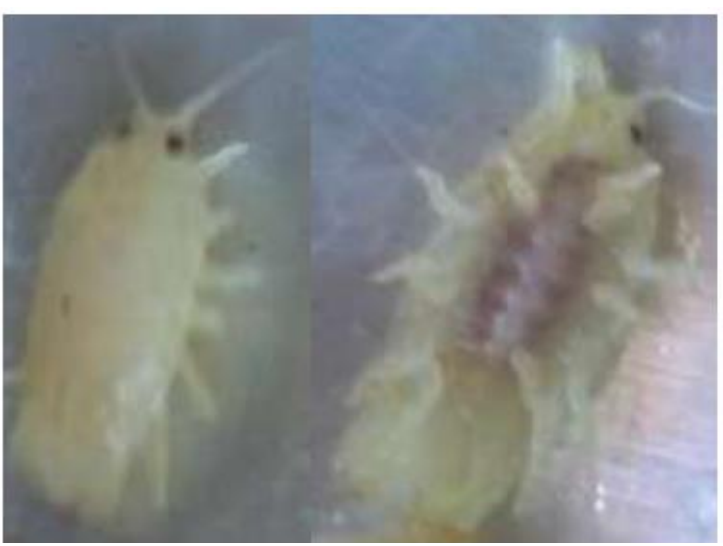

Ectoparasite on dorsal and ventral looks

Figure 2. The grouper fish and its ectoparasite

Table 1. The grouper fish and ectoparasite

\begin{tabular}{llcrrr}
\hline \multirow{2}{*}{ No } & \multicolumn{1}{c}{ Annotation } & $\begin{array}{c}\text { Innitial and final } \\
\text { population }\end{array}$ & \multicolumn{2}{c}{ Fish Checking } \\
\cline { 3 - 5 } & & 1,500 & $\mathrm{I}$ & II & III \\
\hline 1 & Stocking the grouper fish seeds on July 2016 & & 280 & 55 & 85 \\
2 & Letal & & 1,220 & 1,165 & 1,080 \\
3 & Number of populations & & 305 & 292 & 270 \\
4 & Population/FNC & & 684 & 668 & 668 \\
5 & Samples & & 296 & 59 & 90 \\
6 & Attacked fish by ectoparasite & & 472 & 97 & 131 \\
7 & Total ectoparasites & & 43.3 & 8.8 & 13.5 \\
8 & Average prevalence (\%) & & 1.6 & 1.6 & 1.5 \\
9 & Average intensity & & & & \\
10 & Harvesting the grouper fish on 2017 & $\pm 70 \%$ & & & \\
\hline
\end{tabular}




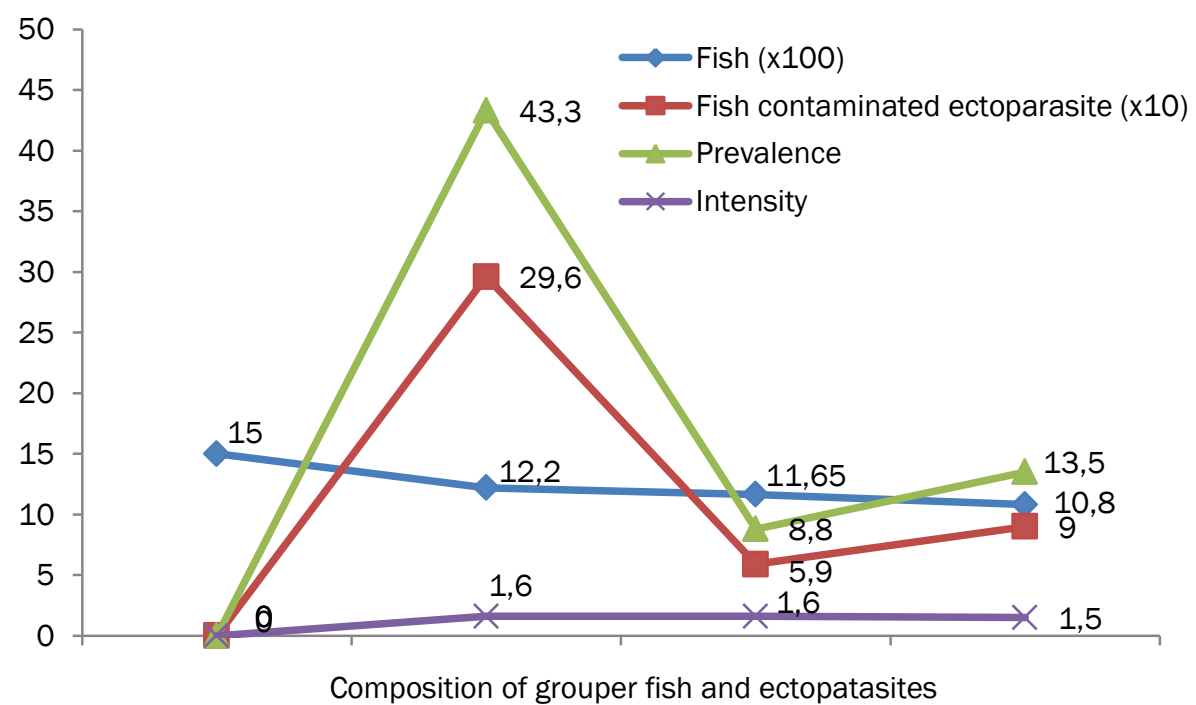

Figure 3. Number of fish and its ectoparasites

Table 2. The hydro-oceanographic condition of waters surrounding Pongok Island

\begin{tabular}{lcccc}
\hline No & Month & Blowing Wind & Seawater current condition*) & $\begin{array}{c}\text { Seawater } \\
\text { Temperature }\end{array}$ \\
\hline 1 & Jul 2016 & Southeast (transition) & Two-way (switchover) & 28.4 \\
2 & Aug 2016 & Southeast & Low & 28.1 \\
3 & Sep 2016 & Southeast & Low & 28.8 \\
4 & Oct 2016 & Southwest (transition) & Normal & 28.7 \\
5 & Nov 2016 & Southwest & Sormal & 29.3 \\
6 & Dec 2016 & Southwest & Strong & 28.7 \\
7 & Jan 2017 & West & Strong & 28.1 \\
8 & Feb 2017 & West & Normal & 28.0 \\
9 & Mar 2017 & Northwest & Normal & 28.1 \\
10 & Apr 2017 & North & Low & 28.7 \\
11 & May 2017 & North & Two-way (switchover) & 29.4 \\
12 & Jun 2017 & North (transition) & 29.2 \\
\hline
\end{tabular}

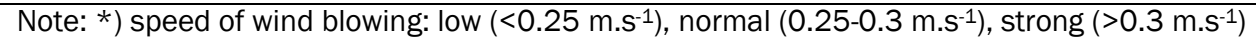

Table 3. The condition of seawater quality parameters in the FNC

\begin{tabular}{|c|c|c|c|c|c|}
\hline No & Parameter & $\begin{array}{l}\text { During high tide } \\
\left(\mathrm{mg} \cdot \mathrm{L}^{-1}\right)\end{array}$ & $\begin{array}{c}\text { During low tide } \\
\left(\mathrm{mg}^{\circ-1}\right)\end{array}$ & $\left.\mathrm{BM}^{*}\right)$ & Method \\
\hline & Nov 23, 2017*) & & & & \\
\hline 1 & Ammonia (NH3-N) & 0.144 & 0.155 & 0.3 & APHA \\
\hline 2 & Nitrate (NO3-N) & 0.089 & 0.150 & - & APHA \\
\hline 3 & Ortho Phosphate (PO4-P) & 0.004 & 0.005 & 0.015 & APHA \\
\hline 4 & Nitrite (NO2-N) & 0.020 & 0.067 & 0.5 & APHA \\
\hline \multirow[t]{2}{*}{5} & Lead $(\mathrm{Pb})$ & 0.024 & 0.027 & 0.008 & APHA \\
\hline & Apr16, 2011*) & & & & \\
\hline 6 & Ammonia (NH3-N) & 0.081 & $0.058-0,132$ & 0.3 & APHA \\
\hline 7 & Nitrate (NO3-N) & 0.031 & $0.011-0.012$ & 0.008 & APHA \\
\hline 8 & Ortho Phospate(PO4-P) & $<0.005$ & $<0.005$ & - & APHA \\
\hline 9 & Nitrite $(\mathrm{NO} 2-\mathrm{N})$ & $<0.002$ & $<0.002$ & - & APHA \\
\hline 10 & Lead $(\mathrm{Pb})$ & 0.028 & $0.019-0.031$ & 0.05 & $\mathrm{APHA}$ \\
\hline
\end{tabular}

Source: Data from survey and analysis, 2017; Adibrata et al., 2013

Note:*) : The water quality standard was based on the Ministerial Decree of Environment Number 51 of 2004 Appendix III (for Marine Biotas). The coordinate location of FNC on November 23, 2017 was $02^{\circ} 52^{\prime} 36,4^{\prime \prime} \mathrm{S} 107^{\circ} 00^{\prime} 58,8^{\prime \prime}$ E; and on April 16, 2011 was $02^{\circ} 52^{\prime} 15,7^{\prime \prime}$ S $107 \circ 01^{\prime} 10,7^{\prime \prime} \mathrm{E}$ 
from the ectoparasites. However, there were still a number of ectoparasites originating from remaining unchecked fish and coming up the sea bottom below the FNC which presumably function as the which killed 85 fish. This is supposedly a number of ectoparasites coming from most unchecked fish before and/or swimming up from the seafloor surrounding environment due to an effect of hydrooceanographic conditions.

The grouper seedlings attacked by the ectoparasites in the FNC were physically seen moving un-normally (the fish moved sideways), weak, and their skin, fins, and gills were blistered, as well as they breathed on the seawater surface, or lean (possessing a big head and slim body). Furthermore, the parasite prevalence is varied on groupers, for all leopard coral grouper (Plectropomusleopardus) is 40\% (Sauyai et al., 2014), and the highest happened on common pandora fish (Pagellus erythrinus) with a size range of $16-18 \mathrm{~cm}$ in the coastal areas of El Kala, Aljazair in a summer (Gasmi et al., 2017). The highest prevalence occurred on cantang grouper (Epinephelus fuscoguttatus-lanceolatus) in eastern coast of Pangandaran, Indonesia, which is about 66.6\% (ectoparasite: Diplectanum) and in the traditional FNC is approximately $44.4 \%$ (Diplectanum) (Rostika et al., 2018). Moreover, the prevalence of ectoparasites also happened on fish with sizes in a range of $15-27.5 \mathrm{~cm}$ in the Mariculture Center of Lombok, West Nusa Tenggara, Indonesia, reaches 27.5\% (ectoparasite: Monogenea with Neobenedenia girellae species with a size of 3.8-5.4 x 1.5-2.5 mm in length) attacking the surface of body or skin, eyes, dorsal and ventral fins (Dewi et al., 2018). The fish attacked by parasite Benedenia acanthopagri is about $25.78 \%$ causing an increasing respiratory disorder on opercular and surface movement, gulping atmosphere air, propelling mouth open, bleeding on the base of fin, peeling off on tail, tail fin, and dorsal area; demonstrating different ulcers on body parts, emerging gill blockage (Hassan et al., 2015). The results of this research informed evidence that the prevalence of parasites in a range of $25.78-66.6 \%$ could disrupt enough the cultured fish in the floating net cages and eventually until to be a death level of the fish.

The intensities of ectoparasites during the three checking periods were 1.6, 1.6 and 1.5, respectively. This means that every 10 seedlings of groupers in the FNC are attacked by at least 15-16 ectoparasites. The existence of ectoparasites is very detrimental to fish cultured in the FNC system. Interviewing the fishermen in the research location (fish raisers) implies that the ectoparasites are still there every year event hough their emersion fluctuates, sometimes in a large quantity and at ectoparasite habitat and hideout. Due to this attack, there were 55 grouper seedlings death during this period. This prevalence increased on the last checking (Checking III), namely becoming 13.5\% other times is lower than attack the reared fish. The highest intensity of ectoparasites occurred on the Cantang grouper (Epinephelus fuscoguttatuslanceolatus) in eastern coast of Pangandaran, Indonesia, which is about 2.9 (Ectoparasite: Diplectanum) and in the traditional FNC is about 2 individuals (Ectoparasite: Diplectanum) (Rostika et al., 2018). The highest intensity of ectoparasite attack on Cantang grouper (Epinephelus fuscoguttatus-lanceolatus) occurred in the Lombok Mariculture Center, West Nusa Tenggara, Indonesia, namely approximately 2.75 (Ectoparasite: Monogenea with species Neobenedeni agirellae) (Dewi et al., 2018). This research points out that the intensity of ectoparasites during this research is lower than other locations in Indonesia, however, an intensity of 1.5 is enough to disturb the cultured grouper activity causing many cultured fish died.

Monitoring the hydro-oceanographic condition associated with the presence of ectoparasites is gained from the seawater temperature and seawater current condition. In November 2016, considerable ectoparasite prevalence appeared. This condition was started by a low seawater current flow $\left(<0.25\right.$ m.s $\left.{ }^{-1}\right)$ occurring mainly in August and September 2016, and a low seawater temperature happened especially in August and October 2016 (Table 2). The low seawater current brought about moving up ectoparasites from the seafloor freely without any obstacles to attack the rearing fish. Conversely, a strong seawater current $\left(>0.3 \mathrm{~m} . \mathrm{s}^{-1}\right)$ was able to inhibit the ectoparasites gliding for attaching on the fish. Furthermore, the cold seawater temperature can hasten the metabolism of biota body to equalize its body temperature and the surrounding environment. The aquatic biota body is going to burn quickly the energy which makes it easily get hungry and has to look for a food source. Due to this condition, the ectoparasites enable to look for a host of aquatic biota as their food source. The marine biotas are poikilotherm in where the water temperature is very influential (Singh et al., 2013; Lall and Tibbetts, 2009) on their bodies and escalating their metabolism. The temperature of the environment affects the energy-releasing and nutrition intaking. On a low temperature, fish efficiently utilize their protein and lipid for energy than the carbohydrate (Lall and Tibbetts, 2009). In February 2017, there was low ectoparasite prevalence. This condition was initiated by a strong seawater current flow and a low seawater temperature on the previous month. It is presumed 
that the ectoparasites locating on the sea bottom are difficult to gliding up attaching on the fish in the FNC. Unfortunately, in May 2017, the ectoparasite prevalence increased. This condition emerged because of a normal and low seawater current flow and a low seawater temperature in March. It is assumed that the ectoparasites on the sea bottom come up more freely to attach on the groupers in the FNC.

The condition of seawater quality parameters in the FNC in both periods of 2011 and 2017 was under the quality standard based on the Ministerial Decree of Environment No. 51 of 2004 in Appendix III (for marine biotas) signifying that the water body is able to tolerate inputs of Ammonia, Nitrate, Ortho Phosphate, Nitrite and Lead. This is probably due to the existing condition of FNC is still a little small with a total size only $\pm 1 \mathrm{Ha}$. Based on the water quality data, the chemical elements are still far below the threshold and do not disturb yet the FNC of culture activity in the surrounding waters of Pongok Island. The water quality parameters as the mentioned elements above are not the factors inhibiting the growth and development of ectoparasites.

Based on the field survey, the ectoparasites are supposedly coming from the surrounding environment of the FNC and they do not host on seedlings originating from hatcheries. This information was attested by the ectoparasites attaching on the fishing baits during the fishermen and the researcher conducted a line fishing at nights in the waters nearby location of the FNC on condition of low seawater current and cold temperature. The baits were not eaten by fish but they were swarmed over by the ectoparasites which were identified similarly with species in the FNC. The schooling grouper in the FNC became the target of ectoparasites for candidate hosts. The more FNC contains groupers, the more ectoparasite will increase both attaching on culture fish and the seafloor beneath the cages. The management of fish culture was carried out by cleaning and revoking the ectoparasites attaching on the skin and gills of the reared groupers, cleansing the net cages, and setting the pattern of stocking and harvesting time of the fish on particular months and following the environmental condition as the prevention to the ectoparasites appearing. These techniques are believed to inhibit the ectoparasites which are potentially harming the cultured groupers in the FNC.

\section{Conclusions}

The checking of the grouper fish in three different periods demonstrates the ectoparasites prevalences are 43.3\%, $8.8 \%$ and $13.5 \%$ respectively. This signifies that the highest death of the cultured fish occurs during on checking I and the survival rate of the cultured fish in a year in the FNC is $70 \%$ of total initial stocking seedlings of groupers, namely 1,500 individuals. The intensities of ectoparasites in checking I, II and III are 1.6, 1.6 and 1.5, showing that every 10 groupers in the floating net cage is pottentially attacked by at least 15-16 ectoparasites. The existence of ectoparasites is harmful for culturing fish in the FNC system. The monitoring results of hydro-oceanographic condition point out that the ectoparasite prevalence occurs on two situations, namely during low seawater current flow and low temperature of the seawater. The aquatic biota is poikilothermic and going to be easily hungry in this condition so they have to look for food sources including the ectoparasites. The condition of seawater quality parameter in the location of FNC in both years 2016 and 2017 periods is under the quality standard. The ectoparasites are supposedly originating from the surrounding environment of the FNC and are not hosted on the cultured fish coming from hatcheries. The management of cultured groupers is undertaken by cleaning and revoking the ectoparasites that are being attached on the skin and gills of the grouper fish, cleansing the cage net, and adjusting the stocking and harvesting patterns on certain month following the surrounding water condition as the prevention to hamper the ectoparasites attacking the cultured groupers in the FNC.

\section{References}

Adibrata, S., Kamal, M.M., \& Yulianda, F., 2013. Daya Dukung Lingkungan untuk Budidaya Kerapu (Famili Serranidae) di Perairan Pulau Pongok Kabupaten Bangka Selatan. J. Pesisir dan Pulau-pulau Kecil, 2(1): 43-58.

BPS of South Bangka Regency. The statistics central bureau of South Bangka Regency of 2017. South Bangka in figures. Toboali. [In Indonesian].

Brett, A.I., Fiona, G., \& Peter, L. 2005. Fish health management guidelines for farmed murray cod. Fisheries Victoria Research Report Series No. 32. p. 18

Brown, L. 1993. Aquaculture for Veterinarians. Fish Husbandry and Medicine. Pergamon Press Ltd., Oxford.

Bruce, N.L., Martin, M.B., Hadfield, K.A., \& Nowak, B.F. 2016. Redescription of the fish parasitic "tongue biter" Cymothoarhina Schioedte \& 
Meinert, 1884 (Crustacea: Isopoda: Cymothoidae) from Singapore. Raffles Bull. Zool. Sup. 34: 331-342.

Dewi, N.T.B., Aryadi, I.F., Arrizal, A.F.T., Mardika, D.R., Syahputra, P.A., Subekti, S., Kismiyati, \& Sari, P.D.W. 2018. Monogenean parasites on cantang grouper (Epinephelus fuscoguttatus lanceolatus) wilture in floating net cage for mariculture center Lombok, West Nusa Tenggara, Indonesia. IOP Conf. Series: Earth and Environmental Science 137: 1-7.

Dias, J.D., Simoes, N.R., \& Bonecker, C.C. 2012. Net cages in fish farming: a scientometric analysis. Acta Limnologica Brasiliensia, 24 (1): 12-17. doi: 10.1590/S2179-975X201 2005000022

Gasmi, Y., Belhocine, K., Abdeli, R., \& Khati, W., 2017 Parasitic specificity in the Sparidae family fish Pagellus erythrinus of the El Kala coast, Algeria. AACL Bioflux. 10(4): 721-738.

Hadfield, K.A., Bruce, N.L., \& Smit, N.J. 2014. Review of the fish parasitic genus Ceratothoa Dana, 1852 (Crustacea, Isopoda, Cymothoidae) from South Africa, including the description of two new species. ZooKeys 400: 1-42. doi: 10.3897 /zookeys.400.6878

Hassan, M.A., Osman, H.A.M., Aswathan, M., AlShwared, W.A., \& Fita, N.A. 2015. Infestation of Cage-Cultured Marine Fish with Benedenia acanthopagri (Monogenea; Capsalidae) in Eastern Province of Saudi Arabia. Global Veterinaria. 14: 219-227. doi: 10.5829/ idosi.gv.2015.14.02.9329

Karakassis, I. 2001. Ecological effects of fish farming in the Mediterranean . In: Uriarte, A. \& Basurco, B. (ed.). Environmental impact assessment of Mediterranean aquaculture farms. CIHEAM, Zaragoza.

Kepmeneg-LH No. 51 tahun 2004. The Ministerial Decree of Environment. 2004. Marine Water Quality Standards for Marine Biotas. Jakarta. [In Indonesian].

Kent, M. 2007. The Oxford Dictionary of Sports Science \& Medicine (3 ed). Oxford University Press. http://www.oxford reference. com. doi: 10.1093/acref/978 0198568506.001.0001.

Krejcie, R.V., \& Morgan, D.W. 1970. Determining Sample Size for Research Activities. Educational and Psychological Measurement. 30: 607-610.

Lall, S.P., \& Tibbetts, S.M. 2009. Nutrition, Feeding, and Behavior of Fish. Veterinary Clinics Exotic
Animal 12: 361-372. doi: 10.1016/j.cvex. 2009.01.005.

Nagasawa, K. \& Cruz-Lacierda, E.R. 2004. Diseases of cultured groupers. Southeast Asian Fisheries Development Center, Aquaculture Department, Iloilo, Philippines. 81p.

Novriadi, R., Agustatik, S., Bahri, S., Sunantara, D., \& Wijayanti, E. 2014. Distribusi patogen dan kualitas lingkungan pada budidaya perikanan laut di Provinsi Kepulauan Riau Depik. 3(1): 83-90.

Perda Kab. Bangka Selatan No. 6 Tahun 2014. The Local Regulation of South Bangka Regency. The Spatial Plans of South Bangka Regency for 2014 - 2034. The Local Gazette of South Bangka Regency of 2014. Toboali.

Rostika, R., Ramadhan, F.G., Nurhayati A., \& Rosidah. 2019. Levels of prevalence and intensity of ectoparasites that are contained on grouper fish (Ephinephelus fuscoguttatuslanceolatus) in floating net cage Pangandaran district. Int. J. Fish. Aquat Res.. 4: 17-20.

Sauyai, K., Longdong, S.N.J., \& Kolopita, MEF. 2014. The parasite identification on leopard coral grouper, Plectropomus leopardus. Aquat Cult. 2(3): 76-83.

Silva, F.C., Leite, J.R., Hostim-Silva, M., Valença, A.R., \& Sanches, E.G. 2014. First record of Neobenedenia "melleni" - like species (Monogenea: Capsalidae) in Goliath grouper Epinephelus itajara in Brazil. Braz. J. Vet. Parasitol. 23(1): 248-250. doi: 10.1590/S19 84-29612014025.

Singh, S.P., Sharma, J.G., Ahmad, T., \& Chakrabarti, R. 2013. Effect of water temperature on the physiological responses of Asian catfish Clarias batrachus (Linnaeus 1758). Asian Fish. Sci. 26:26-38.

Syakti, A.D., Hidayati, N.V., \& Siregar, A.S. 2012. Marine Pollutant Agents. IPB Press, Bogor. [In Indonesian].

UU No. 27/2007 jo UU No.1/2014. Act. Coastal regions and small islands management. The state gazette of the Republic of Indonesia of 2007 No. 84, and the state gazette of the Republic of Indonesia of 2014 No. 2. Jakarta.

Wu, R.S.S. 1995. The Environmental Impact of Marine Fish Culture: Towards a Sustainable Future. Mar. Poll. Bull., 31: 159-166. 